\title{
Teaching Skills Level of Female Student Teachers at The University of Petra and its relation to the GPA
}

\author{
Dr.Mahmoud Alsalkhi \\ Dept. of Educational Sciences \\ University of Petra, Jordan \\ Dr. Munier Ajaj \\ Dept. of Educational Sciences \\ University of Petra, Jordan
}

\begin{abstract}
This study aimed at knowing the teaching skills level of female student teachers who are specializing in Class Teacher at University of Petra, and its relation to the GPA. The study sample consisted of 58 female student teachers who are registered in training course of the second semester for the academic year 2016/2017. The two researchers prepared an observation sheet that covers five aspects: planning, teaching procedure (Implementation), evaluation, lesson closure, and class management. The study results indicated an average practice of teaching skills as shown by the female student teachers with an Arithmetic Average of (2.468). Whereas, the performance of the observed sample was high in the areas of teaching procedure and evaluation, average performance in the areas of planning and classroom management, and weak performance in the area of lesson closure. Also, the study results showed no statistical indicative differences attributed to the (GPA).
\end{abstract}

Key Words: Field Training, Teaching Skills.

\section{INTRODUCTION}

Education plays an important role in managing the affairs of individuals as well as societies. As an active human being, he strives to learn the skills necessary for organizing his life in view of changing environment. Since teaching skills are considered an educational tool, and the teacher is the one who can reveal and develop these skills, therefore, he is responsible for directing these skills in the right way and urging his students to practice appropriate activities.

The qualified teacher can enrich and adapt the curriculum in order to meet the needs and interests of his students (Momani, 1993). The teacher should be dedicated to his teaching career through which he can reshape the behavior of his students using his experience and teaching skills in the classroom.

The skill was defined by Zaytoon (1994) as the capability to perform a specific process with a degree of speed and perfection with a minimum effort. Whereas, teaching was defined by Fatlawi (2003) as a complicated process that involves: teacher, teaching material, learner and teaching environment. These elements interact with each other to produce teaching and learning process.

Also, the skill was defined by Huwaidi (2002) as a system of planned actions including planning, implementation, and evaluation aiming at providing students with knowledge, skills, values, and appropriate interests. Therefore, we can define the training skills as a group of procedures based on planning, implementation, evaluation, lesson closure, and class 
management. These procedures will enable the teacher to implement training steps perfectly in order to make desirable changes in the students' behavior with a high degree of satisfaction.

The teaching skills are considered a fundamental milestone on which the teacher should focus in developing and communicating them to the student teachers. These skills are considered indications that measure the effectiveness of the teaching process. Needless to say that scientific and educational development of student teachers will positively reflect on the training process by producing a generation of teachers capable of success and excellence ( Tyler \& Waldrip, 2002).

It is worth mentioning that each one of the main training skills (planning, implementation, evaluation, lesson closure, and classroom management) requires the teacher to apply related minor training skills to support the main skills. The minor skills related to planning should include identifying training objectives and analyzing the lesson material. Also, the supporting skills related to implementation may include display of lesson material, preparing and classifying questions to ensure the motivation of students. Regarding evaluation, the teacher should have the skill of creating achievement tests that cover a wide variety of objective as well as subjective questions. These minor skills are significant in supporting the training process (Khataibah \& Olimat, 2001).

The two researchers believe that the teaching skills should focus on the procedures implemented inside the classroom through the training material. The qualified teacher who has the ability to manage various training situations using his skills and values, which motivate learners to interact with them successfully.

\section{LITERATURE REVIEW}

By reviewing the literature on teaching skills, the two researchers have found the most prominent:

Planning: It is an organized system and method through which the lesson elements are displayed to achieve the planned objectives that lead to the progress of the teaching process. The ability of the teacher to face the challenging teaching situations and solve their difficulties depends on his well planning of the teaching process that helps students comprehend the lesson and understand its concepts and elements (Badawi, 2011).

It is of note that the teacher should carefully plan the time needed to cover a specific portion of the lesson material. This planning will help the teacher cover the planned material on timely basis (Tannawi, 2009). Well planned teaching process helps the teacher to avoid randomness in his work and gives him the chance to plan the lesson objectives in order to manage the time accordingly. The effective planning organizes the teacher's work and gives him career satisfaction (Yamani, 2009).

There are many kinds of planning such as:

\section{Constructive Planning}

This kind of planning requires a group of decisions aiming at long-range planning, and building a new pattern with new systems.

\section{Comprehensive Planning}

This planning requires preparing a plan that shows the objectives and covers the comprehensive curriculum (Khaza'aleh, et al, 2011). 
Teaching Procedures (Implementation): The teacher should have the skills required for effective teaching. These skills include lesson implementation based on a strategy that includes a group of procedures aiming at achieving specific learning objectives (Hila, 2007).

Students should be given the opportunity to participate in taking decisions regarding teaching and social activities. This participation will give students incentive to implement these decisions .

The effective implementation skill attracts the attention of students and motivate them for learning. Also, this skill should ensure a continuous follow up on the progress of students. Since the lesson contains several activities, special preparation is required for each activity in order to achieve the purpose of each specific activity.

Evaluation: It receives special interest by educational personnel. The modern evaluation is considered a part of teaching and learning process. Evaluation was defined by Faraj (2009) as measuring the extent of accomplishing the learning objectives by the end of every teaching period. In view of this evaluation, the success or effectiveness of the applied teaching plan can be determined. Also, evaluation was defined by Zaytoon (1999) as a well-organized process that make a decision of a certain educational process in order to improve or modify the process or some of its elements.

There are various types of evaluation such as:

- Initial (Feasibility) evaluation conducted prior to the teaching process in order to get information related to the main elements of the curriculum.

- Formative evaluation conducted continuously during the teaching process for its development based on the learners' feedback.

- Final evaluation conducted by the end of the teaching process to know the extent of accomplishing the objective of the process and the level of its perfection .

The evaluation is the most capable skill in supporting the effective learning of students. It was noted by Rashid Dosari (2014) that" pre-planning of the teacher and his continuous follow up on the performance of students are the two guarantees for getting the most effective evaluation".

Lesson closure: This skill is important as the lesson display skill. It provides a general review of what has been taught. Also, the teacher may have the time to summarize important information, introduce students to the next lesson, or give them homework assignment. On the other hand, there are undesirable lesson closure s such as moving to a new idea or activity at the end of the class period, or finishing the explanation prior to the end of the class period which leaves students doing nothing.

The lesson closure skill is complementary to the preparation skill. The teacher should plan for the lesson closure as he plans for its implementation. Examples of lesson closure include:

1. Summarizing the main points of the lesson or activity.

2. Directing questions to the learners focusing on the main elements of the lesson.

3. Writing the main points of the lesson on the board.

4. Using drawings to clarify the elements of the lesson.

A science teacher planed his lesson to introduce two main concepts: metals and non- metals After he finished explaining the concept of metals, he told his students "before we move to the non-metallic concept, let us review the main points of the concept of metals" (Tannawi, 2009). 
The two researchers believe that the lesson closure skill should always coincide with the end of class period. This practice gives the students a message that the teaching job is organized in order to produce learning outcomes that emphasizes time management.

Class Management: It is defined as the actions and procedures made by the teacher to create a comfortable learning environment. Organized classroom management ensures an effective teaching process that leads to the planned development of students' skills and talents. Class management is defined by Zuhairi(2015) as "A process aims at creating an effective and organized classroom environment that ensures producing a teaching process in view of the planned learning objectives. Also, effective management leads to the development of students' positive attitudes and motivate them to enhance their interests and desires.

Class management has different styles such as:

- Authoritative Style: It is based on individual authority and opinion, and taking decisions without discussion. This style does not give students any opportunity to participate in planning the teaching process.

- Democrative Style: It gives students equal opportunities to share in planning teaching process or educational decisions.

- Conventional Style: It gives the teacher the role of a father and resists any change in the educational situation that may threaten his authority inside the Classroom (Faraj,2009).

Class Management that takes preventive precautions to prevent any improper students' behavior predicts the existence of a successful teacher who prevents any unacceptable behavior or problems inside the classroom. Following are examples of preventive styles that the teacher can use to prevent such behaviors: availability of proper classroom environment, identify the procedures and rules that control the work inside the classroom, monitoring the learners' behavior, and finally providing proper support (Tannawi, 2009).

\section{STUDY PROBLEM}

The College of Arts and Sciences at University of Petra offers a specialized academic curriculum within the preparation program to qualify teachers of the first primary grades (Class Teacher). This curriculum contains courses of different specialties including: curricula and teaching methods of Islamic Education and Arabic Language. The student teacher is assigned to one of the cooperative schools under the supervision and follow up of specialists in the curricula and teaching methods at the College of Arts and Sciences.

Based on the necessity of developing the level of teaching skills in view of the accelerated development of scientific and technological skills as well as modern teaching methods, there was a critical need for investigating the performance level of the female student teachers for the purpose of developing their teaching skills and improving their performance.

This study is exemplified by answering the following two questions:

- What is the level of teaching skills of the female student teachers at the University of Petra?

- Is the level of teaching skills differs by the (GPA) of the female student teachers at the University of Petra?

\section{STUDY IMPORTANCE}

The importance of this study concentrates on the theory and application aspects. The theory aspect requires the class teacher to posses the teaching skills needed through classroom situation to activate the student's role in the classroom. Whereas, the application aspect 
focuses on investigating the performance level of teaching skills of the female student teachers. The results of current study can positively contribute in developing the teaching skills of female student teachers in the curricula and teaching methods of different specialties.

\section{PREVIOUS STUDIES}

A group of previous studies related to the study research has been reported:

A study conducted by Bhargava \& Pathy (2011) aimed at investigating the teaching competencies needed by student teachers to succeed in the teaching career from their point of view. The study sample was formed from (100) student teachers specialized in education at the Indian Ranshi University. The study results indicated that self-confidence is the most personal competency needed by the student teachers. Whereas, knowledge competency is the most professional competency needed by them. In the light of study results, the two researchers recommended focusing the attention on the $t$ student teachers through continuous comprehension evaluation during the practical educational program.

Another study conducted by Abu swaween (2010) aimed at recognizing the teaching competencies needed, from their point of view, by student teachers specializing in class teacher program at Education College at Al-Azhar University. The researcher used the descriptive analytical method in his study. Also, a format was prepared to survey the competencies needed by the student teachers being surveyed after confirming its credibility and reliability. The survey format covered eight areas consisting of (70) minor qualifications. The format was distributed to the study sample of (112) male and female students of the fourth level (33 males \& 79 females). The study results reveal the needs of the study sample for the competencies of the following identified eight areas: the competencies of lesson display in the first level, the evaluation competency in the second level, competency of lesson closure in the third level. In addition, the competency of making and using the audiovisual aids in the fourth level, followed by the competency of motivating students in the fifth level, and planning competency in the sixth level. Also, the competency of class management and discipline control in the seventh level; Finally, the last level was the competency of identifying the teaching objectives

A study was conducted by Varma (2007) aimed at improving the teaching quality by monitoring the teaching skills of the comprehensive training teachers. The study results indicated the necessity of training teachers on using teaching methods based on students' needs and supported by available teaching aids.

Also, another study was conducted by Shatanawi(2007) aimed at knowing the most important competencies possessed by the female student teachers with Field Teacher specialty (Arts \& Sciences) in the Education College in Oman from the view point of the female cooperative teaches in Al-Thahir schools. In his study, the researcher used the descriptive method. Also, he used a survey format that contains (52) minor competencies distributed over six major fields. The study results revealed the need of the female student teachers for some competencies. Also, the results showed the order of competencies as follows: the competency of shaping the behavioral objectives and handling the lesson content occupied the first level; the classroom management occupied the second level, and human skills in the third level. In addition, the competency of teaching methods occupied the fourth level, evaluation was placed in the fifth level. Finally, teaching personal skills occupied the sixth level. Also, the study results showed no statistical indicative differences, as viewed by the cooperative teachers, between the competencies of the surveyed female student teachers attributed to variables in degree and experience. 
In addition, a study conducted by Ghzewat (2003) aimed at recognizing the level of teaching competencies of student teachers with the specialty of Field Teacher in Humanities at Mo'ata University in Jordan as viewed by the cooperative teachers. The researcher used the descriptive method and survey as a study tool. The study concluded that the students of humanity studies were in need of some competencies such as updating their cognitive and human skills, organizing their self-learning, classroom management, and using the modern teaching methods. Also, the study recommended providing students with the needed competencies as shown by the results.

Another study was conducted by Shehata \& Alsheikh(2002) to recognize the effectiveness of a suggested training program to develop the training skills of female teachers in primary stage in Qatar. The researcher used a semi-empirical method in his study. The survey sample consisted from (213) primary stage teachers in Qatar. The study results confirmed the effectiveness of the suggested training program in developing the teaching skills. Also, the results showed a low level of practicing the teaching skills by the primary stage teachers. The two researchers recommended the development of a preparation program for primary school teachers in Qatar.

Also, another study was conducted by Yeung (2001) to investigate the competencies of the student teacher during the field training in the cooperative schools. The study sample was formed from (120) of student teachers at Hong Kong University. The study results reported a group of obstacles and difficulties faced by the surveyed student teachers such as: low level of field and cognitive skills, lack of kinetic skills, poor time management and behavior control inside classroom. The researcher recommended an increase of field application time, and documenting the performance of the student teachers by the supervisor during evaluation.

A study conducted by (Saunders, et al, 2001) to identify the teaching competencies needed by science teachers in the secondary stage. The study results revealed the lack of interest shown by teachers in teaching methods aids prior to their service.

Also, Hamadi (1996) conducted a study to identify the teaching skills needed by teachers as viewed by supervisors and high school teachers in Qatar. The study tried to answer some questions such as: what are the most important teaching skills needed by teachers? To answer this question, the researcher used a survey format covered 19 items applied on a sample of (278) teachers and (93) supervisors. The results showed the most important teaching skills needed by the teacher were as follows: goals, test preparation, identify the elements that support the teaching process, attract the students' attention, and the selection of a suitable testing tool. Also, the results confirmed the necessity of all teaching skills, and recommended similar studies be conducted on different samples.

A study was conducted by Pakardet (1995) to design a program to train teachers to develop their major teaching skills and class management in Arizona state of USA. The program contained patterns of teacher's personal characteristics and its relation to the student's achievements including: goals identification, planning, decision-making, time effectiveness, career commitment, and finally improvement of teaching methods. The application of the program indicated that the main teaching skills and class management are the most important skills as vied by the teacher. The study recommended conducting similar studies on different samples.

Based on previous studies, researchers believe that there are differences in the level of teachers' practice of their teaching skills. This is attributed to the variety of their academic and educational levels. 


\section{METHODOLOGY}

The study adopted the descriptive analytical method, as it is the most suitable method for handling the study objectives. This method depends on qualitative and quantitative study, which represents the actual situation and gives interpretation for this situation.

The study sample consisted of (58) female student apprentices registered in the field training program offered to the students of Class Teacher specialty at the University of Petra in the second semester of the academic year 2016/2017

An observation sheet was used in this study. It contained items aiming at revealing the practice level of teaching skills by the female student teachers with specialty of Class Teacher at the University of Petra. In order to accomplish the study goals, the study tool was developed by following steps:

- The two researchers conducted exploratory study on a sample of students who are studying the course of field training required for the Class Teacher specialty at the University of Petra. An open question was directed to the students regarding the teaching skills, which they believe should be required by every student teacher with a specialty of Class Teacher.

- The educational literature and previous studies were reviewed regarding the most important teaching skills that must be developed by the teachers of the low primary stage.

- The two researchers classified and arranged the answers of the students covered by the survey. Based on the students' feedback and the review of the educational literature, a study tool was developed. The tool was shaped emphasizing the teaching skills, then classified into five areas distributed as follows:

Teaching skills related to planning, that contains (9) items.

- Teaching skills related to the teaching procedures (Implementation), that contains (19).

- Teaching skills related to evaluation, that contains (7) items.

- Teaching skills related to lesson closure, that contains (5) items.

- Teaching skills related to class management, that contains (10) items.

In order to ensure the suitability of the study tool to measure what is supposed to measure, the two researchers presented the tool to a group of teaching staff members from Jordan Universities review. The arbitrators were requested to give their feedback regarding the coverage of teaching tool to all areas of the teaching skills, and the suitability of items to all areas. Also, they were asked to add, modify, or delete any unsuitable item. In view of the feedback of arbitrators, the final version of the study tool was adopted with its (50) items distributed over five areas.

In order to verify the consistency of the study tool, Cronbach 's alpha coefficient was used, and the results are shown below: 
Table1: Cronbach 's alpha coefficient values for the study tool.

\begin{tabular}{|l|c|c|}
\hline \multicolumn{1}{|c|}{ Area } & $\begin{array}{c}\text { No. of } \\
\text { Items }\end{array}$ & $\begin{array}{c}\text { Consistency } \\
\text { Coefficient }\end{array}$ \\
\hline Planning & 9 & 0.792 \\
\hline $\begin{array}{l}\text { Teaching } \\
\text { Procedures(Implementation) }\end{array}$ & 19 & 0.741 \\
\hline Evaluation & 7 & 0.820 \\
\hline Lesson closure & 5 & 0.849 \\
\hline Class Management & 10 & 0.724 \\
\hline Total & 50 & 0.875 \\
\hline
\end{tabular}

\section{RESULTS AND DISCUSSION}

To answer the first question: What is the level of teaching skills of the female student teachers at the University of Petra?

The skill levels were divided into three categories:

- High, Average, and Low. as follows:

* Less than (1.33) low level.

* From 1.34 to 2.67 average level.

* From 2.68 - 4 high level.

The Arithmetic Average and Standard Deviation for each of the five teaching skill areas were calculated as shown in the next table.

Table2: The Arithmetic Average and Standard Deviation for each of the five teaching skill areas

\begin{tabular}{|c|l|c|c|c|}
\hline $\mathbf{N}$ & \multicolumn{1}{|c|}{ Area } & M & S.D. & Level \\
\hline 1 & $\begin{array}{l}\text { Teaching Procedures } \\
\text { (Implementation) }\end{array}$ & 3.086 & 0.5849 & High \\
\hline 2 & Evaluation & 2.756 & 0.530 & High \\
\hline 3 & Planning & 2.668 & 0.715 & Average \\
\hline 4 & Classroom Management & 2.594 & 0.534 & Average \\
\hline 5 & Lesson Closure & 1.237 & 0.953 & Low \\
\hline \multicolumn{2}{|c|}{ Total } & 2.468 & 0.507 & Average \\
\hline
\end{tabular}

As shown in table 2, the overall Arithmetic Average of teaching skill levels was (2.468). This means that the student teachers of Class Room specialty at the University of Petra demonstrated an average performance of practicing their teaching skills. Teaching procedures (implementation) occupied the first level high with an Arithmetic Average of (3.086). Whereas, evaluation occupied the second high level with an Arithmetic Average of (2.756), and class closure was in the lowest level with an Arithmetic Average of (1.237).

The results of current study were different from those of the studies conducted by Shatanawi(2007), Al-Abu swaween (2010), Varma (2007), Yeung (2001) and finally Shehata \& Alsheikh(2002). All these studies reported a low level of teaching skills in the areas of teaching procedures (implementation), class management, and evaluation.

The Arithmetic Average and Standard Deviation for skills of each area were calculated as shown below. 


\section{First: Teaching skills related to Planning.}

Table (3); The Arithmetic Averages and Standard Deviations for teaching skills related to planning.

\begin{tabular}{|c|c|c|c|c|}
\hline $\mathrm{N}$ & Skill & $\mathrm{M}$ & S.D & Level \\
\hline 1 & $\begin{array}{l}\text { Choose the appropriate educational tools } \\
\text { that achieve the objectives of the lesson. }\end{array}$ & 3.5345 & .97721 & High \\
\hline 2 & $\begin{array}{l}\text { Select an appropriate preparation of the } \\
\text { lesson. }\end{array}$ & 3.2759 & .98752 & High \\
\hline 3 & Identify appropriate teaching methods. & 3.2069 & 1.25319 & High \\
\hline 4 & $\begin{array}{l}\text { Determine the suitable time for each } \\
\text { element of the daily plan. }\end{array}$ & 2.8793 & 1.21507 & High \\
\hline 5 & $\begin{array}{l}\text { Formulate the behavioral objectives of } \\
\text { the lesson clearly. }\end{array}$ & 2.8448 & 1.29509 & High \\
\hline 6 & $\begin{array}{l}\text { Analyze the lesson content to its } \\
\text { components. }\end{array}$ & 2.7931 & .91304 & High \\
\hline 7 & $\begin{array}{l}\text { Select appropriate evaluation methods } \\
\text { and lesson closure. }\end{array}$ & 2.7241 & 1.25367 & High \\
\hline 8 & $\begin{array}{l}\text { Select the classroom activities suitable to } \\
\text { the level of students that contribute to } \\
\text { the achievement of goals. }\end{array}$ & 1.4828 & 1.72943 & Average \\
\hline 9 & $\begin{array}{l}\text { Consider the diversity of objectives in the } \\
\text { plan (cognitive, emotional, and } \\
\text { Psychomotor). }\end{array}$ & 1.2759 & 1.05619 & Low \\
\hline & Total & 2.668 & 0.715 & Average \\
\hline
\end{tabular}

This table shows that the overall total of the teaching skills related to planning came up with an Arithmetic Average of (2.668) which means average level. Whereas, the minor skill "Choose the appropriate educational tools that achieve the objectives of the lesson." occupies the first high level with an Arithmetic Average of (3.5345). This high level can be explained by the Class Teacher program given by University of Petra that offers educational courses which emphasized the preparation and application of teaching tools. Also, the teachers in the College of Education train students in the Class Teacher program how to construct the teaching tools in s scientific and practical method, and how to select the suitable tools that accomplish the lesson goals.

Also, the minor skill "Consider the diversity of objectives in the plan (cognitive, emotional,\& Psychomotor) occupied the lower level with an Arithmetic Average of (1.2759). This result is attributed to the fact that the student teachers usually focus on cognitive area of the plan.

The results of this study are different from those results obtained by Abu swaween (2010) that reported a week level of the planning area. Also, the results of this study are different from those results of Saunders, et al (2001) that reported lack of student teachers' interest in determining the teaching methods and the selection of the suitable training audiovisual aids. 


\section{Second: Teaching skills related to the lesson procedures (implementation)}

Table 4: The Arithmetic Averages and Standard Aviations of the teaching skills related to the lesson procedures.

\begin{tabular}{|c|l|c|c|c|}
\hline $\mathrm{N}$ & \multicolumn{1}{|c|}{ Skill } & \multicolumn{1}{|c|}{$\mathrm{M}$} & \multicolumn{1}{|c|}{ S.D } & Level \\
\hline 1 & Introduce teaching tools at the right time. & 3.8103 & .39545 & High \\
\hline 2 & Distribute questions fairly among students. & 3.6724 & .57393 & High \\
\hline 3 & Keep clarity of sound and diversity of tone. & 3.6034 & .59056 & High \\
\hline 4 & $\begin{array}{l}\text { Be proficient in the content of the subject } \\
\text { being taught. }\end{array}$ & 3.5862 & .67628 & High \\
\hline 5 & Ask students clear and suitable questions. & 3.3621 & .74217 & High \\
\hline 6 & $\begin{array}{l}\text { Follow a logical and coherent sequence in } \\
\text { lesson presentation }\end{array}$ & 3.2414 & .88477 & High \\
\hline 7 & $\begin{array}{l}\text { Adhere to the steps of the lesson: } \\
\text { (preparation - presentation - evaluation and } \\
\text { closure). }\end{array}$ & 3.1552 & .72067 & High \\
\hline 8 & $\begin{array}{l}\text { In general, diversify teaching methods such } \\
\text { as (collaborative learning, closure } \\
\text { dialogue, discussion, etc.) }\end{array}$ & 3.1207 & .67739 & High \\
\hline 9 & $\begin{array}{l}\text { Use the correct Arabic language that suits the } \\
\text { level of students. }\end{array}$ & 3.0862 & .92309 & High \\
\hline 10 & Develop students' thinking skills. & 3.0517 & 1.14589 & High \\
\hline 11 & Use the whiteboard effectively. & 3.0172 & .80549 & High \\
\hline 12 & $\begin{array}{l}\text { Hide the teaching tool upon performing its } \\
\text { mission. }\end{array}$ & 3.0000 & 1.05963 & High \\
\hline 13 & $\begin{array}{l}\text { Implement classroom activities in an } \\
\text { attractive manner. }\end{array}$ & 2.9483 & 1.34324 & High \\
\hline 14 & $\begin{array}{l}\text { Link the learning material to the students' } \\
\text { lives and realities. }\end{array}$ & 2.9138 & 1.18890 & High \\
\hline 15 & $\begin{array}{l}\text { Provide the skill of suitable lesson } \\
\text { preparation and its motivation. }\end{array}$ & 2.8276 & 1.01113 & High \\
\hline 16 & Highlight the lesson title on the blackboard. & 2.8103 & 1.54984 & High \\
\hline 17 & $\begin{array}{l}\text { Connect the previous information of } \\
\text { students with the subject of the new lesson. }\end{array}$ & 2.7069 & 1.55607 & High \\
\hline & $\begin{array}{l}\text { Provide feedback after students' answers. } \\
\text { develop them in the students. }\end{array}$ & 2.6724 & 1.09845 & High \\
\hline & 2.0517 & 1.40703 & Average \\
\hline 19 & 3.086 & 0.5849 & High \\
\hline
\end{tabular}

It is clear from the above table that all minor skills (except No.19) that are related to the area of teaching procedures occupied high levels of skills with the Arithmetic Averages in the range of 2.6724 and 3.8103. The exceptional skill "Focus on the values in the lesson, and develop them in the students." was placed at the average level with the Arithmetic Average of 2.0517. The skill of "Introduce teaching tools at the right time" was placed at the first level with an Arithmetic Average of 3.8103. This confirms the result of the planning skill in (Table 3 No.1).

The skill of knowledge competency was rated at a high level in this study, but it is rated at a low level as result of the study conducted by Bhargava \& Pathy, 2011 and Yeyng, 2001. Also, the skill of using teaching methods was rated at a high level in the current study. Whereas, it is rated at a low level in the study of Varma, 2007 


\section{Third: Teaching skills related to evaluation}

Table 5: The Arithmetic Averages and Standard Aviations of teaching skills related to evaluation.

\begin{tabular}{|c|l|c|c|c|}
\hline $\mathbf{N}$ & \multicolumn{1}{|c|}{ Skill } & M & S.D & Level \\
\hline 1 & $\begin{array}{l}\text { Maintain continuity in the evaluation } \\
\text { process. }\end{array}$ & 3.5690 & .65191 & High \\
\hline 2 & Link the evaluation to the lesson goals. & 3.1207 & .85998 & High \\
\hline 3 & Use appropriate evaluation tools. & 3.0690 & .49069 & High \\
\hline 4 & $\begin{array}{l}\text { Explore and reinforce strengths. Also, } \\
\text { diagnose weaknesses and deal with them. }\end{array}$ & 3.0000 & .91766 & High \\
\hline 5 & $\begin{array}{l}\text { Consider an appropriate timing for the } \\
\text { assessment. }\end{array}$ & 2.9483 & .99864 & High \\
\hline 6 & $\begin{array}{l}\text { Take into account the individual } \\
\text { differences when asking questions. }\end{array}$ & 2.8793 & .72735 & High \\
\hline 7 & $\begin{array}{l}\text { Encourage students to practice self- } \\
\text { assessment. }\end{array}$ & 0.7069 & 1.28430 & Low \\
\hline & Total & 2.756 & 0.530 & High \\
\hline
\end{tabular}

This table shows an overall Arithmetic average of (2.756) for the teaching skills in the area of evaluation, which was achieved with a high level. "The Maintain continuity in the evaluation process" skill achieved the first high level with an Arithmetic Average of (3.5690). This explains the emphasis of the training program on connecting the evaluation questions with the pre-identified study goals. Whereas, the skill of Encourage students to practice self-assessment was placed at the lowest level with an Arithmetic Average of (0.7069). This may be due to the limited time available for the student teacher to practice self-evaluation.

The result of this study are different from those obtained by Abu swaween, 2010, Shatnawi, 2007, Shahati \& Al-Shaikh, 2002, and Yeung. 2001. All these studies indicated a low level of teaching skills, and urged teachers to pay attention to this area. 


\section{Fourth: Teaching Skills relate to lesson closure}

Table 6: The Arithmetic Averages and Standard Aviations of teaching skills related to lesson closure .

\begin{tabular}{|c|c|c|c|c|}
\hline $\mathrm{N}$ & Skill & $\mathrm{M}$ & S.D & Level \\
\hline 1 & Select the topic of the next lesson. & 1.4483 & 1.88412 & Average \\
\hline 2 & $\begin{array}{l}\text { Summarize the main points of the lesson } \\
\text { on the blackboard. }\end{array}$ & 1.4138 & 1.72733 & Average \\
\hline 3 & Define the required duties and activities. & 1.2414 & 1.64701 & Low \\
\hline 4 & $\begin{array}{l}\text { Attract students' attention to a natural } \\
\text { end of the lesson. }\end{array}$ & 1.0517 & 1.44395 & Low \\
\hline 5 & Complete the lesson on time. & 1.0345 & 1.60006 & Low \\
\hline & Total & 1.237 & 0.953 & Low \\
\hline
\end{tabular}

The above table shows the overall Arithmetic Averages of the teaching skills related to lesson closure area was (1.237), and placed at a low level with the exception of the first two skills rated at an average level. The first skill "Select the topic of the next lesson" was given an Arithmetic Average of (1.4483). And the second skill "Summarize the main points of the lesson on the blackboard." was given an Arithmetic Average of (1.4138). The reason of these results is attributed to the non-existence of this teaching skill in related educational courses, and ignoring its application by students.

\section{Fifth Skill: Teaching skills related to class management}

Table 7; The Arithmetic Averages and Standard Aviations of teaching skills related to class management.

\begin{tabular}{|c|c|c|c|c|}
\hline $\mathrm{N}$ & Skill & $\mathrm{M}$ & S.D & Level \\
\hline 1 & $\begin{array}{l}\text { Committed to entering and exiting the class } \\
\text { on an exact time. }\end{array}$ & 4.0000 & .00000 & High \\
\hline 2 & Arrange seats assigned to specific students. & 3.7586 & .57156 & High \\
\hline 3 & Keep students busy with useful activities. & 3.0345 & 1.05905 & High \\
\hline 4 & $\begin{array}{l}\text { Adapt to changing and emerging situations } \\
\text { during the lesson. }\end{array}$ & 2.9828 & .88835 & High \\
\hline 5 & $\begin{array}{l}\text { Apply reward and punishment in a proper } \\
\text { educational manner. }\end{array}$ & 2.9655 & 1.18419 & High \\
\hline 6 & Ignore small events or handle them. & 2.4828 & .95956 & Average \\
\hline 7 & $\begin{array}{l}\text { Accept students, and establish good } \\
\text { relations with them. }\end{array}$ & 2.4138 & 1.91974 & Average \\
\hline 8 & Establish the bases of good conduct. & 2.1379 & 1.09941 & Average \\
\hline 9 & $\begin{array}{l}\text { Develop students' positive attitudes } \\
\text { toward self-discipline. }\end{array}$ & 1.6897 & 1.15784 & Average \\
\hline 10 & $\begin{array}{l}\text { Encourage students to take initiative and } \\
\text { ask questions. }\end{array}$ & 0.4828 & .97767 & Low \\
\hline & Total & 2.594 & 0.534 & Average \\
\hline
\end{tabular}

The above table shows the overall Arithmetic Averages of the teaching skills related to class management area was (2.594), and placed at an average level. Also, it is shown that the minor skill "Committed to entering and exiting the class on an exact time" was rated at the first high level with an Arithmetic Average of (4.00). This result was due to the emphasis of the field program on the commitment of participants to its time frame. In addition, the minor skill "Encourage students to take initiative and ask questions." was rated at the lowest level with an 
Arithmetic Average of (0.4828). The researcher explained this low performance by the unavailability of adequate experience of the student teachers to reactivate their positive role. This may be due to the tension that trainees sometimes feel. In order to ensure successful class management and effective training, friendly relations between teachers and their students need to be established based on mutual respect and confidence.

The results of this study agree with those results reported by Pokuredle.1995 that showed high level of teaching skill related to class management. Whereas, the study results are different from those reported by Abu swaween, 2010, Al-Ghzaiwan, 2003, Shihata \& Al-Shaikh, 2002, and Yeung that revealed low level of teaching skills related to evaluation, and the need of teachers to pay attention to it.

To answer the second question: does the teaching level of student teachers at University of Petra differ by the (GPA)? A variation analysis of one direction was performed for the five areas of the teaching skills that were practiced by the student teachers in the Class Teacher program during their field training. Table 8 illustrates the results of variation analysis for the five areas.

Table 8: The results of variation analysis of teaching skill levels of student teachers according to the variable of their (GPA)

\begin{tabular}{|c|c|c|c|c|c|c|}
\hline Variable & & $\begin{array}{c}\text { Sum of } \\
\text { Squares }\end{array}$ & Df & $\begin{array}{c}\text { Mean } \\
\text { Square }\end{array}$ & F & Sig. \\
\hline Planning & Between Groups & 1.789 & 4 & 0.447 & 0.865 & 0.491 \\
& Within Groups & 27.384 & 53 & 0.517 & & \\
& Total & 29.173 & 57 & & & \\
\hline Teaching & Between Groups & 0.791 & 4 & 0.198 & 0.638 & 0.638 \\
Procedures & Within Groups & 16.415 & 53 & 0.310 & & \\
& Total & 17.206 & 57 & & & \\
\hline Evaluation & Between Groups & 0.811 & 4 & 0.203 & 0.705 & 0.592 \\
& Within Groups & 15.230 & 53 & 0.287 & & \\
& Total & 16.041 & 57 & & & \\
\hline Lesson & Between Groups & 1.672 & 4 & 0.418 & 0.442 & 0.778 \\
Closure & Within Groups & 50.124 & 53 & 0.946 & & \\
& Total & 51.797 & 57 & & & \\
\hline Classroom & Between Groups & 1.267 & 4 & 0.317 & 1.119 & 0.357 \\
Management & Within Groups & 15.001 & 53 & 0.283 & & \\
& Total & 16.268 & 57 & & & \\
& & & & & & \\
\hline
\end{tabular}

It is clear from Table 8 that no existence of statistical indicative differences between the teaching skill levels of student teachers in the five areas attributed to the (GPA). The " $\mathrm{F}$ " values of $(0.865,0.638,0.705,0.442$, and 1.119$)$ confirm the above result, as no " $\mathrm{F}$ " value is statistical indicative. Also, this result can be explained by the fact that all student teachers study the same study plan and attend the same lectures. Although the student teachers show differences in the test results of theoretical knowledge, and subsequently in the (GPA), these results do not give indicator about students' skills in the field training. However, the (GPA) is only an indicator that does not measure all performance variables.

\section{CONCLUSION}

It is obvious from study results that teaching skills level was high in the areas of teaching procedures (implementation) and evaluation, an average level in the area of class management and planning. Whereas, the teaching skills level was low in the area of lesson closure 
Also, the study results showed weak performance of student teachers in some minor teaching skills such as:

- Planning Area: Consider the diversity of objectives in the plan (cognitive, emotional, and Psychomotor).

- Evaluation Area: Encourage students to practice self-assessment.

- Lesson closure Area: Define the required duties and activities, attract students' attention to a natural end of the lesson, and complete the lesson on time.

- Area of Class Management: Encourage students to take initiative and ask questions.

\section{RECOMMENDATIONS}

In light of the study results, the two researchers recommended:

- Emphasizing the practical applications during the theoretical teaching more effectively, and not focusing only on theory.

- Giving students practical assignments for discussion inside the lecture hall, and involving them in preparing daily plans focusing on goals.

- Reactivating the mini teaching method inside the College of Education.

- Urging the supervisors of field training to emphasize the teaching skills that students need to develop and enhance their training experience.

\section{References}

Abu swaween, R.(2010). Educational Competences Needed for Student-Teachers Elementary Schools in the Faculty of Education at Al-Azhar University from their Perceptions Based on their Training Needs, IUG Journal of Islamic University-Gaza, 18(2), 359-398.

Badawi, R. (2011), Curriculum and Teaching Methods, Dar Al-Fikr, Amman, Jordan.

Bhargava, A. and Pathy, M. 2011. Perception of Student Teachers about Teaching Competencies, American International Journal of Contemporary Research, 1(1): 77- 81.

Dosari, R. (2014), Modern classroom assessment Dar Amjad, Amman.

Faraj, A.(2009), Effective Teaching, Dar Al Thaqafa, Amman, Jordan

Fatlawi, S(2003), Introduction to Teaching, Dar al- Shorouk,Amman Jordan.

Ghzewat, M.(2002).Teaching Capabilities Available to Teachers Under Trainning in the Area of Social Studies at Mou'ta University from The Perspective of Cooperative social Studies Teachers at Kark Province Schools at Jordan and Its effect an Students Learning, Umm Al Qura University Journal of Human and Social Sciences, 14(1), 9-30.

Hammadi, A. (1996). Teaching Skills for Teachers from the Point of View of Teachers and guidance at the Secondary stage in Qatar, Hawlia of College of Education (13), 337-362

Hila, M. (2007), Teaching Skills,Dar Al-Masirah, Amman, Jordan.

Huwaidi, Z. (2002), Effective Teaching Skills, Dar Alkitab, Alain.

Khataibah, A.,\& Olimat,A (2001), Assessment of science teachers in Jordan for the level of their teaching skills in the light of some variables, Damascus University Journal, 17 (1) 261-279.

Khaza'aleh, M., Alzobon,M., Khaza'aleh,Kh., Al-Shobaki, A, and Al-Sakhani, H.(2011), Effective Teaching Methods, Dar Al-Safa, Amman, Jordan.

Momani, M . (1993), The role of the teacher in the educational process, Education, UAE,47, 32-41.

Packard, R,.\& others(1995). Professors collaborating on Building a model of Essential teaching and classroom management skills a major Reform program. Paper presentsd at the Annual meeting of the American Association of school Administrators, San Francisco,CA, February 23024,23-26.

Saunders, G., Dawson, C., \& Tripp, B.(2001).Laboratory Skills and Competencies for Secondary Science Teachers. National Edu, Association.

Shatanawi, A.(2007). Female Student Teachers Competencies as Perceived by Cooperating Teachers of Al-

Zhahirah, Journal of Educational and Psychological Studies, Sultan Qaboos University,5(1), 119-158. 
Shehata, M and Alsheikh, N (2002). The effectiveness of a proposed training program in the development of teaching skills among the mathematics teachers in the primary stage, Journal of Curriculum and Instruction Studies, (83), 88- 139

Tannawi, E. (2009), Effective Teaching: Planning, Skills, Strategies, and Evaluation, Dar Al-Masirah, Amman.

Tyler, R. \& Waldrip, B.(2002). Improving primary sconce school experience of change, Australia primary and Junior Science, 18(4).23-28.

Varma, Ch. (2007). Improving Quality of Elementary Education By Monitoring Professional Competencies of Teachers for Inclusive Education. ERIC-Education Resources Information Center (ED494892).

Yamani, A (2009), Teaching and Learning Strategies, Zamzam, Amman, Jordan.

Yeung, W. (2001). The Performance of Pre-Service Student Teacher (Physical Education) During Teaching Practice in Hong Kong, A paper Submitted for Discussion at 21 International Seminar for Teacher Education (ISTE), College of Education, Kuwait.

Zaytoon , A. (1994), Methods of Teaching Science, Dar Al Shorouk, Amman,.

Zaytoon , K. (1999), Teaching: Models and Skills,: Scientific Office for Computer, Publishing and Distribution, Alexandria

Zuhairi, H. (2015), Effective Teaching, Dar Al-Yazuri, Amman,. 